J. Amer. Soc. Hort. Sci. 117(2):243-247. 1992.

\title{
Drought, Paclobutrazol, Abscisic Acid, and Gibberellic Acid as Alternatives to Daminozide in Tomato Transplant Production
}

\begin{abstract}
Joyce G. Latimer'
Department of Horticulture, Georgia Experiment Station, University of Geogia, Griffin, GA 30223

Additional index words. Lycopersicon esculentum, conditioning, field establishment, plant growth regulators, stem shear 'strength, infrared thermometry, yield

Abstract. 'Floradade' tomato (Lycopersicon esculentum Mill.) transplants treated with foliar sprays of paclobutrazol at $0,14,30,60$, or $90 \mathrm{ppm}$ exhibited reductions in stem length, leaf area, and plant dry weight in a cubic response pattern. Gibberellic acid (GA) drenches, at 10,100 , or $250 \mathrm{ppm}$, increased stem length, leaf area, and plant dry weight. Daminozide (2500 or $5000 \mathrm{ppm})$ sprays reduced leaf area and dry weight, but $5000 \mathrm{ppm}$ had no effect on stem length. Abscisic acid drenches, at 275, 660, or $1320 \mathrm{ppm}$, did not affect final plant size. In subsequent experiments to produce transplants for field evaluation, plants treated with paclobutrazol sprays at $90(1987)$ and $14 \mathrm{or} 60 \mathrm{ppm}$ (1988) had smaller leaf area, stem length, and shoot dry weight than untreated plants. In 1987,90 ppm paclobutrazol reduced stem shear strength, while $2500 \mathrm{ppm}$ daminozide increased stem strength relative to controls. In 1988,2500 ppm daminozide increased transplant growth while $660 \mathrm{ppm}$ abscisic acid had no effect. Paclobutrazol (14 ppm) and drought improved field establishment of transplants as measured by shoot dry weight gain after field planting. In 1988, total fruit yield was reduced by $60 \mathrm{ppm}$ paclobutrazol and GA. Although fruit size was unaffected by treatments, fruit number was reduced by GA. Chemical names used: butanedioic acid mono (2,2-dimethylhydrazide) (daminozide); B-[(4-chlorophenyl)methyl]- $\alpha$-(1,1-dimethylethyl) -N-1,2,4-triazole-1-ethanol (paclobutrazol).
\end{abstract}

The use of plant growth regulators (PGRs) to control the growth and improve the quality of greenhouse-grown bedding plants is standard procedure in most commercial operations. Daminozide is the growth regulator most' commonly applied to bedding plants to control growth. However, tomato transplant response to daminozide has been variable (Orzolek, 1986), and, in 1989, the usage label for daminozide was restricted to nonfood crops. Therefore, daminozide is no longer available for use on vegetable plant species. Paclobutrazol is very effective in controlling the growth of many crops and may offer an alternative for use in vegetable transplant production (Davis and Curry, 1991). Since paclobutrazol is currently registered (Cultar, ICI Americas, Goldsboro, N. C.) for use on food crops such as apple, peach, and Citrus, it may provide an alternative to daminozide. Although uniconazole, a similar triazole compound, applied to tomato transplants reduced total yield, the yield of large fruits ( $\geq 110 \mathrm{~g}$ ) was increased and blossom-end rot was nearly eliminated (Wang and Gregg, 1990).

Abscisic acid (ABA) and treatments, such as drought and chilling, that tend to increase ABA content in seedlings are used as conditioning treatments for vegetable transplants (Berkowitz and Rabin, 1988; Dufault and Melton, 1990; McKee, 1978). ABA applied immediately before planting reduced transplant shock of bell pepper and increased early and total yields under stress conditions (Berkowitz and Rabin, 1988) but had no effect on the water balance and re-establishment of tomato (McKee, 1978). GA stimulated transplant recovery of cabbage seedlings (McKee, 1981) but had no effect on growth or establishment of tomato transplants (Arteca, 1982).

The following studies were undertaken to evaluate the PGRs, ABA, GA, and paclobutrazol, and drought as alternatives to daminozide. The treatments were evaluated for control of plant

Received for publication 3 May 1991. Accepted for publication 28 Oct. 1991. The cost of publishing this paper was defrayed in part by the payment of page charges. Under postal regulations, this paper therefore must be hereby marked advertisement solely to indicate this fact.

'Assistant Professor. growth in the greenhouse during transplant production, improvement of transplant condition and field establishment, and effects on subsequent crop yield.

\section{Materials and Methods}

Greenhouse experiments. Two greenhouse experiments were conducted in Spring 1987 to determine PGR rates to be used in production of transplants for field experiments. Individual 'Floradade' tomato seedlings were transplanted into plastic cell packs (cell dimensions: $3.8 \times 3.8 \times 6.0 \mathrm{~cm}$ ) containing a peat/pine bark medium (Metro-Mix 300, Grace Horticultural Products, Cambridge, Mass.) to a final plant density of 485 plants $/ \mathrm{m}^{2}$ Seedlings were watered with liquid fertilizer at $200 \mathrm{mg} \cdot \mathrm{liter}^{-}$ (N-P-K) twice per week beginning after seedling emergence. PGRs were applied 4 days after transplanting.

In the first experiment, GA (Pro-Gibb, Abbott Laboratories, North Chicago, 111.) and ABA (mixed isomer, Sigma, St. Louis) were applied as a drench to the planting medium of seedlings at 18 days after sowing (DAS). We used $2.0 \mathrm{ml}$ per cell at concentrations of $0,10,100$, or 250 ppm GA, or, 0, 275, 660, or $1320 \mathrm{ppm}$ ABA. Greenhouse temperatures during the experiment averaged $25 / 14 \mathrm{C}$ (day/night) with an average photosynthetic photon flux (PPF) of $9.9 \mathrm{~mol} \cdot \mathrm{m}^{-2} \cdot \mathrm{day}^{-1}$.

In a second experiment, daminozide (B-Nine, Uniroyal Chemical Co., Raleigh, N. C.) and paclobutrazol (Bonzi, Sandoz Crop Protection Corp., Chicago) treatments were applied as foliar sprays of $1.5 \mathrm{ml} /$ plant with a hand-held spray bottle at 14 DAS. This volume provided thorough coverage of the small seedlings. Paclobutrazol rates were 0, 14, 30, 60, or $90 \mathrm{ppm}$. Daminozide was applied at 0, 2500, or $5000 \mathrm{ppm}$. Greenhouse temperatures during the experiment averaged $27 / 14 \mathrm{C}$ (day/night) with a PPF of $17.6 \mathrm{~mol} \cdot \mathrm{m}^{-2} \cdot \mathrm{day}^{-1}$.

In each experiment, the treatments were arranged in a randomized complete block design with 12 plants per treatment

Abbreviations: ABA, abscisic acid; DAS, days after sowing; GA, gibberellic acid; PGR, plant growth regulator. 
with four replications. Two to 3 weeks after treatment, six plants per treatment were randomly harvested from each replication to determine leaf area (with a LI-COR 3000 leaf area meter, LICOR, Lincoln, Neb.), stem length, and dry weights (after drying for $72 \mathrm{~h}$ at $70 \mathrm{C}$ in a forced-air oven) of leaves, stems, petioles, and roots (obtained by hand-washing them free of the medium).

Field experiments. In Mar. 1987, one rate of each PGR was selected based on the results of the greenhouse experiments. Two-week-old seedlings were transplanted as described above and treated with PGRs 1 week later. PGR treatments were foliar sprays of $90 \mathrm{ppm}$ paclobutrazol or $2500 \mathrm{ppm}$ daminozide or a medium drench of $10 \mathrm{ppm}$ GA. ABA was omitted due to problems with maintaining the ABA in solution. An untreated control and a drought treatment were included. Plants were drought stressed by drying to visible wilting for $\approx 2 \mathrm{~h}$ daily, beginning 1 week after transplanting to cell packs. Treatments (one flat of 72 plants each) were arranged in a randomized complete block design with three replications. Greenhouse temperatures during the experiment averaged 28/15C (day/night) with average PPF of $21.1 \mathrm{~mol} \cdot \mathrm{m}^{-2} \cdot \mathrm{day}^{-1}$.

Four weeks after treatment, four plants per treatment from each replication were harvested for growth measurement as described above. Four additional plants per treatment were randomly selected from each replication for determination of stem shear strength as described by Latimer et al. (1988). Diameter (electronic digital caliper) and length of the internode between the cotyledonary node and the first true leaf were measured before the section was sheared. Maximum shear force was measured using a modified Warner-Bratzler meat shear test cell on an Instron Model 1132 Food Testing System (Instron Corp., Canton, Mass.) equipped with a 500-kg load cell.

On 27 Apr. 1987, fifty of the remaining plants from each treatment in each replication were transplanted $60 \mathrm{~cm}$ apart in rows $90 \mathrm{~cm}$ apart (one row per treatment in each of three subplots) in a field (Cecil sandy loam soil, Typic Halpludult) previously fertilized with $13 \mathrm{~N}-6 \mathrm{P}-11 \mathrm{~K}$ at $900 \mathrm{~kg} \cdot \mathrm{ha}^{-1}$. The randomized complete block design was maintained in the field. Plants were watered by sprinkler irrigation about twice weekly (based on pan evaporation values) to prevent drought stress. Early fruit production was lost to untimely rainfall promoting infection by Phytophthora rot organisms. The remaining fruits were harvested from a 10-plant section of row of each subplot at weekly intervals, 1-31 July.

In Mar. 1988, the field experiment consisted of 14- and 60ppm treatments of paclobutrazol since detrimental long-term plant growth effects occurred at the 90-ppm rate in the 1987 experiment. The same rates of the other PGRs were repeated along with $660 \mathrm{ppm}$ ABA and the control and drought treatments. Two seeds per cell were sown directly into the cell packs described above; however, to improve recovery of the roots during washing, a peat/vermiculite (Pro-Gro 200, Premier Brands, New Rochelle, N. Y.) medium was used. Selecting for uniformity in height and leaf area, the seedlings were thinned to one per cell and treatments were initiated at 21 DAS. Treatments were arranged in a randomized complete block design with one flat per treatment with four replications. Greenhouse temperatures during this experiment averaged $31 / 15 \mathrm{C}$ (day/night), with an average PPF of $22.4 \mathrm{~mol} \cdot \mathrm{m}^{-2} \cdot \mathrm{day}^{-1}$. Five weeks after treatment, six plants per treatment were harvested from each replication for growth measurement as previously described.

On 2 May 1988, the remaining plants were transplanted to another portion of the field described above with the same plant spacings and cultural management practices. The randomized complete block design was maintained in the field, one row per treatment subplot in each of the four replications. A 12-plant section of row of each subplot was designated for yield determination. The total number and fresh weight of fruits harvested weekly for 5 weeks are expressed on a per-plant basis. To monitor field establishment, at 7 and 14 days after transplanting, six plants were randomly selected from the remaining plants in each treatment subplot for determination of shoot dry weight. Plant adaptation to field conditions was also characterized using an infrared thermometer (Scheduler Plant Stress Monitor, Standard Oil Engineered Materials Co., Solon, Ohio). Baseline data were collected in the greenhouse 10 days before transplanting by measuring the differences between canopy and air temperatures, taking three measurements of each flat in each of the four replications. At 10 and 17 days after transplanting to the field, canopy temperatures were again measured, sampling six plants from each treatment in each replication. In the field, care was taken to maintain the infrared thermometer at a constant distance from the plants to insure a small sample area $(7 \times 6.5-\mathrm{cm}$ oval $)$ and prevent interference by soil temperatures.

Statistical analyses. Data were subjected to analysis of variance and regression analysis using the general linear models procedure of SAS (Freund et al., 1986). Mean separation of PGR effects on transplant growth was by orthogonal contrasts for GA and paclobutrazol to select the rates to be used in subsequent field experiments. Orthogonal linear contrasts also were determined for paclobutrazol to model effect of rate on plant growth but were not applied to the GA data due to the limited number and wide range of concentrations tested. Mean separation of treatment effects on transplant growth and subsequent yield was by least significant difference (LSD) at $P=0.05$ for field experiments. An adjusted shear force value was determined by correcting for stem diameter effects on the maximum shear force using covariate analysis. Differences between treatments were determined using a least square means comparison. To determine field establishment, homogeneity-of-lines tests were performed by regressing the log transformation of shoot dry weight over days after transplanting (Latimer, 1990). Separate lines were fitted for each treatment and parameter estimates were separated by a standard $\mathrm{t}$ test.

\section{Results and Discussion}

Greenhouse experiments. Relative to the untreated controls, GA increased leaf area by $\approx 70 \%$ and stem length by $40 \%$ to $278 \%$ with significant contrasts for increasing rates (Table 1). GA also increased tomato plant dry weights. These results are consistent with previous studies (Smith et al., 1990). ABA had no effect on any measurement of transplant growth in this experiment (data not presented).

Plant growth in the second greenhouse experiment was greater than in the previous experiment, presumably due to the higher mean daily light levels and slightly higher temperatures. Paclobutrazol reduced tomato transplant growth measured 14 days after treatment (Table 1). Paclobutrazol decreased final leaf area $30 \%$ to $40 \%$ and resulted in a $50 \%$ reduction in stem length and a $37 \%$ to $52 \%$ reduction in shoot dry weight relative to untreated tomato plants. Dry weights of individual plant parts were reduced similarly $(P<0.05$, data not presented). Although a significant cubic response to paclobutrazol rate was most obvious with final root dry weight, all measurements of plant growth had a consistent cubic response to rate; the greatest reductions in plant growth occurred at $14 \mathrm{ppm}$ and the least growth reduction, relative to untreated plants, at $60 \mathrm{ppm}$. 
Table 1. Effect of plant growth regulators on growth of 'Floradade' tomato transplants in the greenhouse $(\mathrm{n}=24)$.

\begin{tabular}{lccccc}
\hline $\begin{array}{l}\text { Growth } \\
\text { regulator }\end{array}$ & $\begin{array}{c}\text { Concn } \\
(\mathrm{ppm})\end{array}$ & $\begin{array}{c}\text { Leaf } \\
\text { area } \\
\left(\mathrm{cm}^{2}\right)\end{array}$ & $\begin{array}{c}\text { Stem } \\
\text { length } \\
(\mathrm{cm})\end{array}$ & $\begin{array}{c}\text { Shoot } \\
\text { dry wt } \\
(\mathrm{mg})\end{array}$ & $\begin{array}{c}\text { Root } \\
\text { dry wt } \\
(\mathrm{mg})\end{array}$ \\
\hline GA & 0 & 28 & 6.9 & 118 & 26 \\
& $10 \mathrm{D}$ & 45 & 9.7 & 160 & 30 \\
& $100 \mathrm{D}$ & 47 & 14.6 & 154 & 26 \\
& $250 \mathrm{D}$ & 49 & 19.2 & 168 & 26 \\
Orthogonal contrasts & & & & & \\
$\quad$ 0 ppm vs. other rates & & $* * *$ & $* * *$ & $* * *$ & NS \\
10 vs. 100 ppm & & NS & $* * *$ & NS & $*$ \\
10 vs. 250 ppm & & $*$ & $* * *$ & $*$ & $*$ \\
100 vs. 250 ppm & 0 & 102 & 16.6 & 452 & 115 \\
Paclobutrazol & $14 \mathrm{~S}$ & 62 & 7.9 & 216 & 66 \\
& $30 \mathrm{~S}$ & 60 & 7.8 & 238 & 80 \\
& $60 \mathrm{~S}$ & 71 & 8.2 & 284 & 100 \\
& $90 \mathrm{~S}$ & 67 & 7.9 & 274 & 96 \\
Orthogonal contrasts & & & & & \\
Linear & & $* * *$ & $* * *$ & $* * *$ & $* * *$ \\
Quadratic & & $* * *$ & $* * *$ & $* * *$ & $* * *$ \\
Cubic & & $* * *$ & $* * *$ & $* * *$ & $* * *$ \\
\hline
\end{tabular}

${ }^{2} \mathrm{D}$ : Drenches were applied to the medium as $2.0 \mathrm{ml} / \mathrm{plant}$. S: Spray applications were $\approx 1.5 \mathrm{ml} /$ plant.

NS,*,*****Nonsignificant at $P=0.05$ or significant at $P<0.05$, 0.01 , or 0.001 , respectively.

Both rates of daminozide decreased leaf area $\approx 25 \%$ and shoot dry weight $35 \%$ relative to untreated plants $(\mathrm{P}<0.05)$. Final leaf and petiole, dry weights of plants treated with either rate of daminozide were $35 \%$ and $39 \%$ less than those of untreated controls, respectively, but root dry weight was reduced $33 \%$ by 2500 ppm daminozide and $48 \%$ by the $5000-\mathrm{ppm}$ rate (data not presented). Although $2500 \mathrm{ppm}$ daminozide decreased stem length $41 \%, 5000 \mathrm{ppm}$ had no effect on stem growth (16.5 vs. 16.6 $\mathrm{cm}$ for control plants). Daminozide was characteristically inconsistent in managing the growth of tomato transplants (Orzolek, 1986), while paclobytrazol markedly inhibited transplant growth.

Field experiments. In 1987, tomato seedlings were treated with PGR rates expected to reduce the growth of the transplants in the greenhouse and, perhaps, to provide carry-over effects in the field. Paclobutrazol at $90 \mathrm{ppm}$ reduced transplant leaf area $45 \%$, stem length $60 \%$, and total plant dry weight $32 \%$ relative to untreated controls (Table 2). Neither $2500 \mathrm{ppm}$ daminozide nor drought affected tomato transplant growth relative to the untreated control plants. GA (10 ppm) reduced plant dry weight $35 \%$ but did not affect stem length in 1987.

In 1988, delays in field preparation resulted in larger (and older) transplants than in the previous year. Paclobutrazol at 14 and $60 \mathrm{ppm}$ reduced final leaf area $>35 \%$ and stem length $60 \%$ relative to untreated tomato plants (Table 2). Daminozide, however, increased leaf area and plant dry weight $\approx 15 \%$ and did not reduce stem length. GA increased leaf area and stem length but not plant dry weight, resulting in plants that appeared leggy and pale green. ABA did not affect transplant growth. However, in 1988 , the drought treatment, which was more severe than in 1987 due to the larger size of the transplants, reduced growth in a manner similar to paclobutrazol. Drought or water management is used as a growth control tool by many transplant producers, although long-term detrimental effects on plant productivity have been reported with severe stress (McKee, 1981).

Stem characteristics. In 1987, only paclobutrazol (90 ppm). affected internode length (68\% reduction) or diameter $(22 \%$ increase) of 7-week-old tomato transplants (Table 3). A shorter, thicker stem is generally considered an indication of a stronger, more sturdy plant. However, the maximum force required to shear stems of paclobutrazol-treated plants was 50\% less than that required to shear stems of untreated plants, which indicates weaker rather than stronger stems. McDaniel et al. (1990) found that foliar sprays of $25 \mathrm{ppm}$ paclobutrazol eliminated wall thickening of phloem fiber cells in poinsettia (Euphorbia pulcherrima Wind. et K1.) stems, resulting in structurally weaker stems. The adjusted shear force (maximum shear force corrected for stem diameter effects) indicates even greater differences between the stem strength of paclobutrazol-treated and untreated tomato plants. However, the reduced stem shear strength of paclobutrazol-treated plants did not result in increased tomato plant breakage during the mechanical transplanting procedure or affect transplant survival in the field.

Although other growth retardants also may adversely affect stem anatomy (McConnell and Struckmeyer, 1971; McDaniel et al., 1990), daminozide increased the maximum force required to shear tomato transplant stems $20 \%$ relative to untreated plants (Table 3). Treatment differences between daminozide and GA or drought were no longer significant using the adjusted shear force, indicating that treatment differences in maximum shear force could be attributed to differences in internode diameter. Neither GA nor drought affected internode length, diameter, or the force required to shear tomato stems relative to untreated

Table 2. Effect of plant growth regulators or drought on growth of 7- (1987) or 8-week-old (1988) 'Floradade' tomato plants in the greenhouse.

\begin{tabular}{|c|c|c|c|c|c|c|c|}
\hline \multirow[b]{2}{*}{$\begin{array}{l}\text { Growth } \\
\text { regulator }\end{array}$} & \multirow[b]{2}{*}{$\begin{array}{l}\text { Concn }^{2} \\
(\mathrm{ppm})\end{array}$} & \multicolumn{3}{|c|}{$1987(\mathrm{n}=12)$} & \multicolumn{3}{|c|}{$1988(n=24)$} \\
\hline & & $\begin{array}{c}\text { Leaf } \\
\text { area } \\
\left(\mathrm{cm}^{2}\right)\end{array}$ & $\begin{array}{c}\text { Stem } \\
\text { length } \\
(\mathrm{cm})\end{array}$ & $\begin{array}{l}\text { Plant } \\
\text { dry wt } \\
\text { (mg) }\end{array}$ & $\begin{array}{c}\text { Leaf } \\
\text { area } \\
\left(\mathrm{cm}^{2}\right)\end{array}$ & $\begin{array}{l}\text { Stem } \\
\text { length } \\
(\mathrm{cm})\end{array}$ & $\begin{array}{c}\text { Plant } \\
\text { dry wt } \\
\text { (mg) }\end{array}$ \\
\hline Control & -- & 146 & 26 & 1120 & 186 & 30 & 1430 \\
\hline \multirow[t]{3}{*}{ Paclobutrazol } & $14 \mathrm{~S}$ & $-\cdots$ & --- & --- & 115 & 11 & 940 \\
\hline & $60 \mathrm{~S}$ & $\ldots$ & --- & -- & 120 & 12 & 1160 \\
\hline & $90 \mathrm{~S}$ & 80 & 10 & 758 & --- & -.. & --- \\
\hline Daminozide & $2500 \mathrm{~S}$ & 139 & 26 & 1100 & 210 & 32 & 1690 \\
\hline GA & $10 \mathrm{D}$ & 133 & 25 & 934 & 215 & 38 & 1570 \\
\hline Abscisic acid & $660 \mathrm{D}$ & -- & $\cdots$ & -- & 181 & 29 & 1300 \\
\hline Drought & $\cdots$ & 145 & 27 & 948 & 97 & 18 & 860 \\
\hline $\operatorname{LSD}(P=0.05)$ & & 18 & 1.3 & 180 & 15 & 2.4 & 169 \\
\hline
\end{tabular}

${ }^{z}$ Treatments were applied to 21 -day-old seedlings. Solution concentrations: $\mathrm{S}=$ foliar spray, $1.5 \mathrm{ml} /$ plant; $\mathrm{D}=$ medium drench, $2.0 \mathrm{ml} /$ plant. 
Table 3. Effect of plant growth regulators on internode diameter and force required to shear stems of 7 -week-old 'Floradade' tomato transplants in $1987(\mathrm{n}=12)$.

\begin{tabular}{|c|c|c|c|c|c|}
\hline $\begin{array}{l}\text { Growth } \\
\text { regulator }\end{array}$ & $\begin{array}{c}\text { Concn }{ }^{2} \\
(\mathrm{ppm})\end{array}$ & $\begin{array}{c}\text { Internode } \\
\text { length } \\
(\mathrm{cm})\end{array}$ & $\begin{array}{c}\text { Internode } \\
\text { diam } \\
(\mathrm{mm})\end{array}$ & $\begin{array}{c}\text { Max } \\
\text { shear } \\
\text { force } \\
(\mathrm{kg})\end{array}$ & $\begin{array}{c}\text { Adjusted } \\
\text { shear } \\
\text { forcey } \\
\text { (kg) }\end{array}$ \\
\hline Control & -- & 5.9 & 4.52 & 18.9 & 19.6 \\
\hline Paclobutrazol & $90 \mathrm{~S}$ & 1.9 & 5.51 & 9.6 & 9.5 \\
\hline Daminozide & $2500 \mathrm{~S}$ & 5.0 & 4.74 & 22.7 & 22.7 \\
\hline $\mathrm{GA}$ & $10 \mathrm{D}$ & 6.2 & 4.31 & 19.8 & 21.1 \\
\hline Drought & -- & 5.6 & 4.55 & 20.2 & 21.0 \\
\hline $\operatorname{LSD}(P=0.05)$ & & 0.9 & 0.37 & 2.5 & 2.5 \\
\hline
\end{tabular}

${ }^{2}$ Treatments were applied to 21 -day-old seedlings. $S=$ foliar spray, $1.5 \mathrm{ml} / \mathrm{plant} ; \mathrm{D}=$ medium drench, $2.0 \mathrm{ml} / \mathrm{plant}$.

yAll shear force values adjusted to same internode diameter by covariate analysis and differences determined by analysis of LS means.

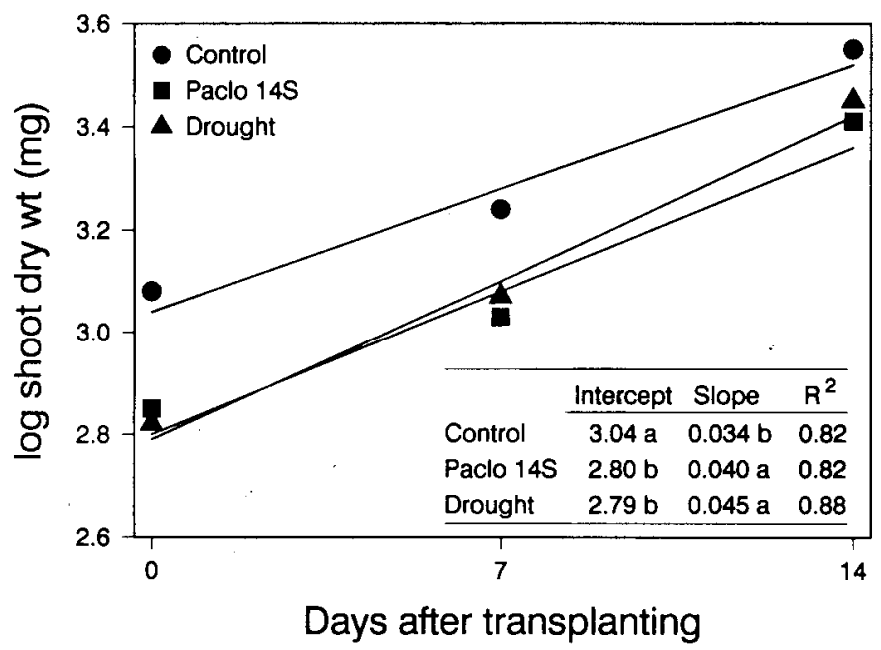

Fig. 1. Effect of $14 \mathrm{ppm}$ paclobutrazol and drought on shoot dry weight gain of 8-week-old 'Floradade' tomato during the first 14 days after transplanting to the field in 1988. Table within figure shows regression equations. Separate lines were fit for each treatment and parameter estimates were separated by a standard $t$ test (n $=24)$.

controls. Severe drought may induce stem pithiness in tomato transplants, which causes a weakened, hollow stem (Aloni and Pressman, 1981).

Field establishment. In 1988, 14 ppm paclobutrazol and drought hastened field establishment of transplants relative to that of untreated plants. The treated plants were initially smaller but gained shoot dry weight faster during the first 14 days in the field compared to control plants (Fig. 1). Rapid re-establishment is an indication that transplants are better able to withstand the stresses of transplanting by having the necessary growth reserves or the ability to regain proper water balance for the resumption of growth (McKee, 1981). Paclobutrazol improved tolerance to drought stress in apple (Malus domestica Borkh.) seedlings (Swietlik and Miller, 1983) and increased soluble sugar accumulation and chlorophyll content in pepper (Capsicum annuum L.) transplants (Aloni and Pashkar, 1987). Both of these responses improve transplant establishment (McKee, 1981). Drought also increased the total sugar content of soybean (Glycine max. L.) seedlings, whereas exogneous ABA had no effect (Creelman et al., 1990). The rate of shoot dry weight gain was not affected by the higher rate of paclobutrazol or the other
PGRs (slopes not significantly different from that of control at $P=0.05)$.

Infrared thermometry. Ten days before transplanting, plants treated with paclobutrazol or drought were under higher stress than the controls, as indicated by higher canopy than ambient air temperatures. While the canopy temperature of control plants was O.1C higher than air temperature, both rates of paclobutrazol increased the temperature difference to $2.9 \mathrm{C}(\mathrm{P}<0.05)$. Since measurements were taken around solar noon, the droughted plants were under obvious stress (canopy temperature 4.OC higher than air temperature, $P<0.05$, relative to control), but all other plants were fully turgid. Paclobutrazol decreased stomatal aperture and increased epicuticular wax in chrysanthemum [Dendrathema grandiflorium (Ramat.) Kitamura], thereby reducing water loss under stress conditions (Smith et al., 1990). These results, taken with our increased leaf temperatures, suggest that transpiration is reduced in paclobutrazol-treated plants. Canopy temperatures measured at 10 and 17 days after transplanting indicated no differences between the stress levels of plants pretreated with the different PGRs or exposed to drought. At this time, canopy-to-air temperature differences ranged from 3.3 to $4.3 \mathrm{C}$ and 2.7 to $3.5 \mathrm{C}$, respectively. However, the temperature differences for paclobutrazol-treated plants measured in the field (3.8C at 10 days and $3.1 \mathrm{C}$ at 17 days) are also very similar to those measured under nonstress conditions in the greenhouse. Infrared thermometry may provide a reliable, nondestructive means of evaluating transplant stress in the field once plants are large enough to fill the field of view.

Crop yield. In 1987, early yield was lost to Phytophthora infection and there was no effect of transplant treatment on the total yield (kilograms per plant) of fruits harvested later in the season (data not presented). However, fruits harvested from droughted or paclobutrazol-treated plants were smaller than those from untreated plants (controls, $195 \mathrm{~g} /$ fruit; $90 \mathrm{ppm}$ paclobutrazol, $158 \mathrm{~g} /$ fruit; drought, $164 \mathrm{~g} /$ fruit; $P<0.05$ ). In 1988 , total fruit yield of transplants previously treated with $60 \mathrm{ppm}$ paclobutrazol or $10 \mathrm{ppm}$ GA was reduced relative to that of untreated tomato plants (Table 4). However, only GA reduced the number of fruits harvested. There were no significant treatment effects on fruit size (grams per fruit).

Since paclobutrazol is more persistent in plant systems than daminozide or many other commonly used plant growth regulators, the upper limit of rates recommended must be determined by field evaluation of the transplants. Final plant size in the field was reduced in 1987 with the high rate of paclobutrazol (90 ppm), and in 1988, $60 \mathrm{ppm}$ paclobutrazol reduced fruit

Table 4. Effect of plant growth regulators or drought applied to transplants on subsequent total fruit yield of 'Floradade' tomato harvested weekly 5 July -9 Aug. 1988.

\begin{tabular}{lcccc}
\hline Treatment & $\begin{array}{c}\text { Fruit } \\
\text { Concn }^{2} \\
(\mathrm{ppm})\end{array}$ & $\begin{array}{c}\text { fresh wt } \\
\text { (kg/plant) }\end{array}$ & No. fruits/plant & $\begin{array}{c}\text { Mean fruit } \\
\text { fresh wt } \\
\text { (g/fruit) }\end{array}$ \\
\hline Control & -- & 3.59 & 29 & 127 \\
Paclobutrazol & $14 \mathrm{~S}$ & 3.89 & 31 & 127 \\
Paclobutrazol & $60 \mathrm{~S}$ & 2.60 & 26 & 108 \\
Daminozide & $2500 \mathrm{~S}$ & 3.51 & 28 & 128 \\
GA & $10 \mathrm{D}$ & 2.35 & 17 & 136 \\
Abscisic acid & $660 \mathrm{D}$ & 3.25 & 28 & 114 \\
Drought &.-- & 3.69 & 29 & 130 \\
LSD $(P=0.05)$ & & 0.75 & 7 & NS
\end{tabular}

${ }^{z}$ Treatments were applied to 21-day-old seedlings. $\mathrm{S}=$ foliar spray, $1.5 \mathrm{ml} /$ plant; $\mathrm{D}=$ medium drench, $2.0 \mathrm{ml} /$ plant. 
yield. Even in 1988, paclobutrazol-treated plants still appeared smaller than controls after 3 months in the field. However, 14 ppm paclobutrazol improved field establishment of transplants and caused no reduction in fruit number or yield. Paclobutrazol may prove to be more reliable than daminozide was for growth regulation of tomato transplants during production. Long-term growth effects may be desired where tomato growers find reductions in labor and supplies for maintenance of smaller plants, provided that rates that do not affect crop yield are established (Vavrina and Armbrester, 1990).

Neither GA nor ABA, at the rates tested, is an effective alternative to daminozide for tomato transplant production or improvement of field establishment. However, in 1988, drought, like $14 \mathrm{ppm}$ paclobutrazol, reduced transplant growth in the greenhouse and improved field establishment without affecting crop yield or fruit size. However, management of drought stress for control of transplant growth and conditioning is more difficult than chemical control. It is difficult to obtain regular cyclic drought of young or small plants, while the potential for excessive stress of large transplants is high. Severe drought stress may not only reduce final plant productivity (McKee, 1981) but also can induce physiological disorders such as hollow stem (Aloni and Pressman, 1981). With the other potential benefits of chemical management of tomato transplants, such as predictable growth control and reduced blossom-end rot (Wang and Gregg, 1990), the triazole growth retardants should be considered as potentially acceptable alternatives to daminozide.

\section{Literature Cited}

Aloni, B. and T. Pashkar. 1987. Antagonistic effects of paclobutrazol and gibberellic acid on growth and some biochemical characteristics of pepper (Capsicum annuum) transplants. Scientia Hort. 33: 167177.

Aloni, B. and E. Pressman. 1981. Stem pithiness in tomato plants: The effect of water stress and the role of abscisic acid. Physiol. Plant. 51:39-44.

Arteca, R.N. 1982. Effect of root applications of kinetin and gibberellic acid on transplanting shock in tomato plants. HortScience 17:633634.

Berkowitz, G.A. and J. Rabin. 1988. Antitranspirant associated abscisic acid effects on the water relations and yield of transplanted bell peppers. Plant Physiol. 86:329-331.
Creelman, R. A., H.S. Mason, R.J. Bensen, J.S. Boyer, and J.E. Mullet. 1990. Water deficit and abscisic acid cause differential inhibition of shoot versus root growth in soybean seedlings. Plant Physiol. 92:205-214.

Davis, T.D. and E.A. Curry. 1991. Chemical regulation of vegetative growth. Critical Rev. Plant Sci. 10:151-188.

Dufault, R.J. and R.R. Melton. 1990. Cyclic cold stresses before transplanting influence tomato seedling growth, but not fruit earliness, fresh-market yield, or quality. J. Amer. Soc. Hort. Sci. 115:559563.

Freund, F. J., R.C. Littell, and P.C. Spector. 1986. SAS System for linear models. SAS Institute, Cary, N.C.

Latimer, J.G. 1990. Drought or mechanical stress affects broccoli transplant growth and establishment but not yield. HortScience 25:1233-1235.

Latimer, J. G., R.B. Beverly, and B. Blum. 1988. Analysis of shear force data in broccoli transplant studies. HortScience 23:627.

McConnell, D.B. and B.E. Struckmeyer. 1971. The effects of succinic acid, 2,2-dimethyl hydrazide on the anatomy of Tugetes erects L. J. Amer. Soc. Hort. Sci. 96:70-73.

McDaniel, G. L., E.T. Graham, and K.R. Maleug. 1990. Alteration of poinsettia stem anatomy by growth-retarding chemicals. HortScience 25:433-435.

McKee, J.M.T. 1978. The effect of abscisic acid on the water balance and growth of vegetable transplants during re-establishment. Proc. Joint Brit. Crop Protection Council and Brit. Plant Growth Regulat. Group Symp.-Opportunities for Chemical Plant Growth Regulation. p. 63-68.

McKee, J.M.T. 1981. Physiological aspects of transplanting vegetables and other crops. II. Methods used to improve transplant establishment. Hort. Abstr. 51:355-368.

Orzolek, M.D. 1986. Use of growth retardants for tomato transplant production. Applied Agr. Res. 1:168-171.

Smith, E. F., A.V. Roberts, and J. Mottley. 1990. The preparation in vitro of chrysanthemum for transplantation to soil. 2. Improved resistance to desiccation conferred by paclobutrazol. Plant Cell Tissue Organ Cult. 21:133-140.

Swietlik, D. and S.S. Miller. 1983. The effect of paclobutrazol on growth and response to water stress of apple seedlings. J. Amer. Soc. Hort. Sci. 108:1076-1080.

Vavrina, C.S. and K. Armbrester. 1990. Performance of plant growth regulators on tomato transplants and subsequent field production. Proc. Stand Establishment of Hort. Crops, Apr. 1990. p. 167-172.

Wang, Y.-T. and L.L. Gregg. 1990. Uniconazole controls growth and yield of greenhouse tomato. Scientia Hort. 43:55-62. 